DOI: 10.18778/2084-140X.10.29

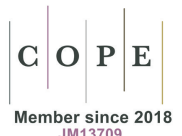

JM13709

\title{
GeOrgios TheоTOKIs, Byzantine Military Tactics in Syria and Mesopotamia in the Tenth Century. A Comparative Study, Edinburgh University Press, Edinburgh 2018, pp. 348.
}

$\mathrm{T}$ he reviewed book was written by Georgios Theotokis, a military historian who graduated from University of Glasgow, and is currently teaching history at the Ibn Haldun University in Turkey. The author belongs to a new generation of scholars dealing with the history of Byzantine warcraft, with particular focus on the reign of the Macedonian dynasty and on military theory. He has written two monographs, numerous well-received articles and has edited a number of collective works.

It is worth emphasizing that although the $10^{\text {th }}$ century is a rather popular period among Byzantine scholars, the reviewed piece is the first such comprehensive attempt to analyze the Byzantine tactics of the $10^{\text {th }}$ century since the publishing of Eric McGeer's work ${ }^{1}$. After a well-written methodological introduction, the author quickly moves on to the actual analysis in the chapter entitled The Grand Strategy of the Byzantine Empire, which is a clear reference to the controversial works by Edward N. Luttwak ${ }^{2}$. Fortunately, G. Theotokis does not try and prove the existence of any grand strategy planned for generations in advance, focusing rather on the strategic importance of the Empire's eastern provinces. The first chapter also includes deliberations on the difference between tactics and strategy, and on the various attitudes to warfare adopted by mercenary forces, with a clear juxtaposition of the culture of bravery represented by west-

\footnotetext{
${ }^{1}$ E. MCGeER, Sowing the Dragon's Teeth. Byzantine Warfare in the Tenth Century, Washington 2008 [= DOS, 33]. ${ }^{2}$ E. LutTwak, The Grand Strategy of the Byzantine Empire, Harvard 2009.
}

ern soldiers of fortune and the culture of tactical order and military trickery represented by Byzantine commanders. The chapter echoes the themes of new military history, and the author is not afraid to touch upon such topics as morale or motivation in war. The second section entitled Strategies and Campaigning Tactics focuses largely on the geography of the contested territories and its direct impact on how wars were fought. A slight omission in this part is the lack of any map of the region in question, which could aid some readers in understanding the historical geography. Chapter three, The Empire's Foreign Policy in the East and the Key Role of Armenia (c. 870-965), is mainly a political analysis of Byzantine-Armenian relations in the context of Byzantine-Arab military conflicts. Theotokis attempts to understand the reasons for the escalating conflict between the Empire and the Hamdanid Dynasty, while taking into account the territory of Armenia, which was the fastest way for any invading force to avoid Byzantine defenses and strike directly into Anatolia. It is an interesting study, bringing a breath of fresh air in certain areas. The final chapter of the historical section is The Empire's Foreign Policy in the East. It contains a chronological breakdown of how the conflict evolved. It is worth noting here that the author is not afraid to utilize Arab sources and does so with care and with the use of appropriate methodology. The section on the transfer of knowledge begins with a short chapter The Byzantine View of their Enemies on the Battlefield: The Arabs, and the next two chapters deal with Reconnaissance, Intelligence and Espionage. The whole part is 
cleverly structured, beginning with thoughts on the state of Byzantine knowledge about their enemies, and extensively documented with quotes from source materials. Chapter seven is an analysis of changes in the tactics of Byzantine armies of the $10^{\text {th }}$ century, both in theory and in practice. Some of the hypotheses presented here are expanded versions of the author's studies on Byzantine tactics, particularly his breakthrough research on the positioning of infantry in mixed-composition armies (i.e. those comprising both footsoldiers and cavalry units) ${ }^{3}$. The author rather comprehensively described the tactical setup of mounted units, including cataphracts, whose emergence in the $10^{\text {th }}$ century drastically changed the situation on the battlefields of the time. In the context of the work's title, this is the key chapter. After identifying the principal changes in Byzantine tactics, the author smoothly moves on to the next chapter, in which he analyzes the causes for these changes, clearly pointing to the intermingling of Byzantine and Arab warcraft. The final two chapters contain a detailed analysis of sources on battles and entire campaigns, attempting to validate the author's theories by studying the practices observed on the battlefields of the $10^{\text {th }}$ century. The book ends with a carefully prepared index and a bibliography.

Assessing the work of G. Theotokis is not difficult. The piece is deeply rooted in the theory of warfare, but the author managed to combine this with practical aspects, analyzing both Byzantine and Arab sources in the two concluding chapters in search of what was actually done in the field. We should also emphasize that the author does not shy away from employing innovative methods of analysis, most prominently seen in the first part of the book. As is the case with any pioneering monograph, certain aspects are slightly lacking. There is no dedicated section on the evolution of Byzantine arms and armor in the period in question, although the topic is not entirely omitted. When analyzing tactics, there are no figures of tactical schemata, which could aid the readers to better

\footnotetext{
${ }^{3}$ G. Theотокіs, The Square Fighting March of the Crusaders at the Battle of Ascalon (1099), JMMH 11, 2013, p. 57-72.
}

understand the more complex issues. I have already mentioned the lack of maps. On the other hand, what the reader does get is a work with an excellent selection of sources, whose author is well-versed in contemporary science, as evidenced in his comments in the footnotes. It is an essential read for anyone studying the Byzantine warcraft of the $10^{\text {th }}$ century, the first monograph of its kind since the publishing of Eric McGeer's work. What is more, G. Theotokis does make use of new methods of analysis, posing intriguing questions and moving beyond certain fixed research patterns. The monograph Byzantine Military Tactics in Syria and Mesopotamia in the Tenth Century is a mandatory source not only for scholars of Byzantine military, but also for those interested in the $10^{\text {th }}$ century in general. The author took a novel approach to studying the conflict between the Byzantium and the Hamdanid Dynasty and we may only hope that it is not his final word on the subject.

\section{BiBLIOgRAPHY}

LutTwak E., The Grand Strategy of the Byzantine Empire, Harvard 2009, https://doi.org/10.2307/j.ctvjhzrf5

McGeer E., Sowing the Dragon's Teeth. Byzantine Warfare in the Tenth Century, Washington 2008 [= Dumbarton Oaks Studies, 33].

Тнеотокіs G., The Square Fighting March of the Crusaders at the Battle of Ascalon (1099), "Journal of Medieval Military History” 11, 2013, p. 57-72.

Łukasz Różycki (Poznań)*

iD http://orcid.org/0000-0002-1536-3387

\footnotetext{
* Adam Mickiewicz University in Poznań, Faculty of History
} 